\title{
The Supernatural Side in Oscar Wilde's the Picture of Dorian Gray
}

\author{
Jean S. Nounadonde \\ Lecturer-Researcher, Department of English studies, Faculty of Arts and Humanities (F.L.A.S.H), University of \\ Abomey-calavi (UAC), Benin
}

*Corresponding Author: Jean S. Nounadonde, Lecturer-Researcher, Department of English studies, Facultyof Arts and Humanities (F.L.A.S.H), University of Abomey-calavi (UAC), Benin

\begin{abstract}
The purpose of this article is to study the supernatural aspects in the Picture of Dorian Gray by the English novelist, Oscar Wilde. In fact, Oscar Wilde in his novel shows the darker side of storytelling by infusing supernatural events to the plot. He also presents situations that inspire nostalgia, fear and tension. Additionally, he evokes darkness and coldness to create an atmosphere of suspense and terror. Last, but not least he also deals with the theme of the inevitability of fate, whichis our lack of control over our destinies.
\end{abstract}

Keywords: Supernatural, darker side, fear, terror, fate, destinies

\section{INTRODUCTION}

Oscar Wilde is not unanimously accepted as a great writer in English literature. Some English critics thing that if he is still remembered, it is because of the "Scandal" that surrounded that phase of his life. He is usually changed with plagiarism, erudition, pseudo-scientism and over-decoration. It is useful to mention here, that his life had a great influence on his writings, which is apparent in the Picture of Dorian Gray because of the element of aestheticism, the doctrine of hedonism, Narcissism and Dandyism. In Addition, homosexuality which ruined his life, is also noticeable in The Picture of Dorian Gray.

Like Edgar Allan Poe, Oscar Wilde wrote of elemental things: of love and death, of the soul with its mysteries of suffering and sin, of human frailties and ideals, of man and God. All these themes may perhaps be reduced to one Common, great, underlying theme: to a sense of one's own guilt. And it seems that he wrote about such themes, either to meet the desire and beliefs of his epoch when speaking of sins, soul, Conscience and body, or to criticize the exaggerated Victorian sense of duty and their moral laws. Indeed,

"..... Victorians were excessively religious, lamentably

Idealistic, nostalgic for the past, and ready to forego

Delights for the Vision of a world beyond". 1

In reading the Picture of Dorian Gray, one is struck by its somewhat religious tone. Innumerable references, some of them very brief and slight, others more taken for granted. So, using the religious influence and the theme of the sense of one's own guilt, Wilde created a supernatural story that owes something to the literature of the Gothic.Oscar Wilde combined elements that belong to the literature of the Gothic, and managed to create the effects he wanted. Thus, either playing upon or playing with our feelings of superstition, he sometimes made a discreet use of fear and suspense or sought the grosser sensations of terror that brutally aimed to the flesh creep. With the mysterious changes in a portrait, and a handsome young man who enjoys the pleasure of a double life; and with the external and internal link between the two, Wilde wrote a remarkable supernatural story that shakes our mind, our nerves and our well Established scientific theories at their foundations. In trying to see beneath the surface of what he exposes to us in his novel, I should analyse the supernatural events and how they

\footnotetext{
${ }^{1}$ Wright, Austin-Victorian literature: Modern Essays in Criticism (A Galacy. New-York Oxford University Press, 1961.
} 
could be explained scientifically or not, in our everyday experience. My interest should also be directed to the way Oscar Wilde conveyed and used the supernatural elements in his novel, while describing the changes in the Portrait and Dorian's eternal youth.

\section{ASPECTS OF THE SUPERNATURAL}

\subsection{The Different Aspects of the Supernatural}

The manifestations of the supernatural are various. The supernatural can be recognised through its context which leads one to hesitate between a rational explanation. Then the supernatural moves the reader, make him doubt himself, frightens him and keeps him in suspense. The supernatural may reside in the transformation of ordinary things into beasts and rational elements, a transformation that is quite unexpected. This aspect of the supernatural is particularly developed in our societies in which, by means of magic or witchcraft, some people endowed with strange power can operate changes in the natural order of the world. A vivid manifestation of the supernatural is illustrated in The Great Ponds, when Aliakoro people decided to kill Olumba, a famous warrior from Chiolu. For this purpose they choose to boil Olumba by using a fragment of his wrapper thorn, a scorpion, the skin cast off by a viper and a plantain stem carved like a man. When all these ingredients had been thrown in the boiling water and the cooking process had started, Olumba began to feel pain.

"....Everywhere Olumba moamed. My head, my chest, my stomach. Chei ! I am burning"2

These practices show that in Africa people can be killed or hurt at a distance. Another aspect of the supernatural is that of people who are born old and grow young. The supernatural may have the aspect of a world inhabited by devils, ghost and all other strange creatures. The supernatural usually rests on a certain belief. The supernatural has the aspect of the bizarre which inThe Picture of Dorian Gray, the dominant aspect of the supernatural resides in the connection between Dorian Gray and his picture. And while the picture is growing old and wrinkled, the man it represents remains young and beautiful. The picture also bears the burdens of Dorian's life. The novel can be considered as a fantastic tale but also a psychological drama but here we are only interested in the fantastic side of the novel.

\section{The SuPERnatural Side In "The PiCture of Dorian GraY"}

The supernatural elements can be explained in the novel through the changes in the expression of the portrait.

The story starts at Basil Hallward's studio, and Oscar Wilde uses the opening chapter of the novel to create an atmosphere quite fertile to the birth of the supernatural. The Supernatural being at obscure world closed to our ordinary understanding of things and Oscar Wilde describes the atmosphere prevailing in Hallward's studio with things that could not be seen in the studio but which express themselves in gloomy figures and sound.

".... And now and then the fantastic shadows of hirds in flight flitted

Across the long tussore-silk curtains that were stretched in from of the

huge window... The sullen murmur of the bees shouldering their way

through the long urmowngrass, or circling with monotonous, seemed to

make the stillness more appressive" ${ }^{3}$

With the evocation of shadows of birds, opium tainted cigarettes, sounds of bees and sound coming from the city; Wilde succeeds in creating an atmosphere of corruption that makes the reader ready to accept any incredible or improbable thing. We can also notice the regular use that Wilde makes of words such as fantastic, fanciful, fantasy, fascinating mysterious and marvelous in order to prepare the reader to accept the events connected with the world of fantasy, mystery fancy, phantoms and so on.

The story of Dorian Gray is about the portrait that Basil Hallward created of a young Adonis named Dorian Gray. We have to explain how the portrait was achieved, its effects on Dorian's life, and the

\footnotetext{
${ }^{2}$ Amadi, Elechi-The Great Ponds (London, Heinemann educational books, 48 Charles street-African series 1970) p. 119.

${ }^{3}$ Oscar, Wilde-The Picture of Dorian Gray P1
} 
supernatural element which are connected with it. The writer introduces us into Basil Hallward's studio, where the painter is just about to finish his latest picture. Basil has many times perpetuated Dorian's features on canvas before, but his latest picture is a real master piece, which the painter does not like to exhibit because he is afraid that he has shown in it the secret of his own soul. He then wishes to because Dorian's good angel and to protect him from the evils of the world. That is why he does not like to introduce Dorianto his friend. Lord Henry, whose wicked theories he does not approve ofHowever. Lord Henry and Dorian met and are at once attracted to each other. Dorian is quite fascinated by Lord Henry low musical voice and brilliant talk. It is under the influence of Lord Henry's tempting theories about the cult of youth, beauty and pleasure seen as modes of perfection and aversion to pain and ugliness as modes of imperfection that Dorian first realized his youth and beauty, their importance in his life, and what use he can make of them. Therefore, Dorian expresses the mad wish that he, himself should remain young and the picture grow old.

".... How sad it is ! I shall grow old and horrible dreadful. But this picture will remain always young. It will never be older than this particular day of June... If it were only the other way! If it were I who was to be always young and the picture that was to grow old.For that-I would give everything! Yes there is nothing in the whole world! would not give ! I would give my soul for that". ${ }^{4}$

The idea of a young man selling his soul in exchange for youth and beauty is old in the history of literature but Oscar Wilde claims to have given it a new form. This fanciful fatal wish uttered by Dorian for eternal youth and beauty, is consummated by a devil's pact in which the face on the canvas bears the burdens of this passions and sins, in return for lasting beauty with final gothic retribution. Indeed, Dorian's terrible wish in granted. And the first supernatural event that allows to say sois the result of this love affair with the beautiful young actress Sibyl Vane. Dorian falls in love with Sibyl Vane because of her beautiful acting, that after having learnt to know the reality of love, the girl cannot act well any more, and Dorian leaves her in spite of her plea for pardon. It is new that Dorian, for the first time he notices the change in the picture.

"In the dim arrested light that struggled through the cream-coloural silk blinds the face appeared to him to be a little changed. The expression looked different. One would have said that there was a touch of cruelty in the month. ${ }^{5}$

This supernatural event has the aspect of something strange, something disdainful and horrible. But what are their manifestations?

\subsection{Manifestations of the Supernatural in the Picture of Dorian Gray}

I can say that Dorian is under a kind of psychological strain. Having exposed his fatal wish he is in a sort perpetual state of expectation waiting for the picture to bear the burdens of his life. Being under such mental strain, Dorian Gray gets the illusion, the expression-when he brutally rejects the actress Sibyl Vane-that a touch of cruelly is added to the features of the portrait. The change is perhaps a creation, a result of Dorian's own imagination which makes him see things in a way that is different from their real shape. And it seems that the general atmosphere of the room at that precise moment the dim arrested light that struggled through the cream-coloured silk blinds favoured such a mystical conclusion. The impression that a change has occurred in the portrait, is certainly the result of the dark and dismal hour of night on Dorian's mind. This change in the portrait being the proof that Dorian's wish has been fulfilled. I can say that the transformation is possible through the substitution that takes place between Dorian Gray and the portrait. With the appearance of the look of evil, and the touch of cruelty in the mouth, the real Dorian that is to say the portrait, is no more than a beast. The portrait is now the external symbol of Dorian's conscience and soul. It has become the reflexion, the mirror of this soul and life. Through the portrait, Dorian is now able to follow the evolution of his aging and corruption.

After that terrible and strange event, Dorian is about to repent when he hears of Sibyl Vane's death from Lord Henry. Out of curiosity, Dorian goes to check whether change has occurred in the portrait, but there is no change in the portrait, for it seems that the thing on the canvas has received the news of

\footnotetext{
${ }^{4}$ Oscar, Wilde-The picture of Dorian Gray $\boldsymbol{P . 3 3}$

${ }^{5}$ Oscar Wilde-The picture of Dorian Gray P.103
} 
Sibyl's death before Dorian Gray himself. Thanks to Lord Henry's calming words, Dorian's face remains without any strain of grief whereas the portrait already bears a look of evil and a touch of cruelty in the mouth. The substitution here is obvious because while Dorian remains insensitive to the death of Sibyl Vane, the portrait which is the real Dorian shows signs of evil. Throughout my explanation of the substitution which operates between Dorian Gray and his picture, it is undeniable that a very chose communication exists between them, something like telepathy.

"For a moment he thought of praying that the horrible sympathy that existed between him and his picture might cease" ${ }^{6}$

To create this supernatural event, Oscar Wilde uses a love affair between Dorian and Sibyl Vane. The result is that, Dorian Gray receives with joy and apprehension the realization of his wish. It is now sure that the picture will be Dorian's guide through life, and also the record of his activities in life.

Now that Dorian's prayer has been answered, he is unable to bear the loathsome appearance of his portrait which is the visible symbol of his soul. He is ashamed of it, and his first step is to hide it away in the forsaken playroom of his innocent childhood, at the top of his house Psychologically speaking, the picture is significant enough, and has to be kept away from the eyes of his servant, and the prying eyes of the outside world. In order to forget the hideousness of the picture, the reproachful accusation of his conscience, and his own desire to live perfectly and fully, without having to worry about his sins and sorrows, Dorian Gray feels the necessity to apply to that poisonous theory that Lord Henry teaches him.

"Nothing can cure the soul but the senses, just as nothing can cure the Senses but the soul"7 Dorian's first attempt to cure his soul by means of the senses is the use of a book. This book has been sent to him by Lord Henry. The book exercises over Dorian's mind a strange influence from which, he cannot free himself for years. As a result, instead of helping him to redeem his soul from the sins he has committed, the book fortifies him in his negative conception of life. In reading this book, Dorian Gray finds nothing to deter himself from his strange and misleading behavior. Dorian's second attempt to cure the soul by means of senses is the use of jewels and the stories created about them. Jewels have the extraordinary virtues of making people invisible or protecting them against poison and the plague. Sometimes, he indulges in the study of perfumes. He discovers the power that perfums have, of creating different moods in people. No less important is Dorian's interest in embroideries, tapestries, ecclesiastical vestments, and everything connected with the service of the church. Moreover, Dorian begins to make a regular consumption of opium and drugs in which he can drown his remorse. These drugs and opium are anodynes to his pains and sorrows. Giving way to consumption of such drugs, Dorian Gray exposes himself to all sordid things.

Consequently, the portrait does not remain indifferent to Dorian's continual inward moral putrefaction. For the portrait is now completely part of his life. That strange link between the portrait and him becomes so strong that, Dorian cannot allow himself to be separated from it for a long time. The painting on the canvas becomes a recipient of every feeling experienced by Dorian. It becomes the record the diary of his life. It is a strange book that day after day, writes the daily-life-story of Dorian Gray. And such as, the fact on the canvas does not fail to record Dorian's different hypocritical attempts to cure his dreadful soul by senses. So, in the line of this sympathy another to bear the burdens of his life-the picture shows signs of sensuality.

"he would examine with minute cure, and sometimes with a monstrous and terrible delight, the hideous lines that seared the wrinkling forehead, or crawled around the heavy sensual mouth" ${ }^{8}$

The appearance of lines of sensuality and hideousness in the picture is a supernatural event of a grotesque kind. It contributes to give a general expression of the bizarre to the picture, an expression that is not far from the image of a ghost. The supernatural event here has a gothic aspect with the terrifying resemblance to a ghost that is discernible in the new expression of the portrait. It seems that a sort of duality exists between Dorian and his picture which is the visible symbol of his and the representation of his conscience.

\footnotetext{
${ }^{6}$ Oscar, Wilde-The picture of Dorian Gray P. 119

${ }^{7}$ Oscar, Wilde. The picture of Dorian Gray $\boldsymbol{P} .28$

8 Oscar, Wilde-The picture of Dorian Gray $\boldsymbol{P} .143$
} 
Besides, there is no palpable, no concrete, no visible connection between the picture and Dorian Gray. So, Dorian's soul and conscience are external to his body thanks to the picture. However, although the picture and Dorian seem to be separated, they are in the fact united by invisible links as far as conscience, soul and body are concerned. Therefore, in order to reach his aim of creating a supernatural event of which the reader will have a memorable idea, Oscar Wilde devotes the chapter 11 to describe the queer practices of Dorian Gray. He also resorts to certain catchwords to impress the reader and to impose on him the supernatural world in which these fantastic events are taking place. On the one hand, some of these catchwords express certainty, something absolute and superlative. Such words are exactly, absurdly, extravagantly, fantastically, supremely, inevitably, impossibly and so on. They are words that let the reader have no other choice, no other alternative in his rational mind. On the other hand, some of the catchwords used by Wilde to express doubt, approximation, and relativity are probably, rather, somewhat, undoubtedly, almost, certainly, nearly, hardly, and so on. These words have the power of making the reader doubt his own ability to come to a concrete rational explanation.

The appearance of loathsome red dew in the portrait is a remarkable supernatural event. Basil Hallward pays Dorian a visit in order to enquire about the rumours which are going round about him. Basil tries in vain to find out the truth concerning the horrible sins that are attributed to Dorian, but he gets evasive answers and understands that before knowing the truth he should have to see Dorian's soul. Dorian's degradation, instead of being apparent in his body, is apparent in his picture because his soul destined to bear his sins, is already apparated from his body. I can say that Basil Hallward's portrait of Dorian is the embodiment of Dorian's and Dorian fulfils his decision to show his sinful soul to Basil, who is highly surprised to notice the change in his own handiwork.

The fact that he could have the same reaction as Dorian shows that the change in the picture is not a fancy on Dorian's part. The shock that the sight of the picture produces on Basil, demonstrates that its alteration is real, and has nothing to do with imagination or the result of a psychological attitude. Inspired by an uncontrollable feeling of hatred, Dorian Gray takes a knife and stabs the painter in the neck. In doing so, he is guided by the idea that, he is destroying the man who is at the origin of the fatal portrait. But the killing of Basil does not put an end to Dorian's misery and sorrows. But on the contrary, his troubles are to continue with the appearance of loathsome red dew on the hand of the portrait.

"What was that loathsome red dew that gleamed, wet and glistening on one of the hands, as through the canvas has sweated blood? How horrible it was!"”

With the appearance of that loathsome red dew on the hand of the portrait, we reach a new development in the course of the supernatural events and in our analysis of the supernatural element in The Picture of Dorian Gray. The portrait becomes a sort of the living thing, bearing fresh lines of recent sins. Indeed, Oscar Wilde made a considerable use of religious ideas and beliefs. The religious idea for instance, that has a consequence of the realization of a prayer, a portrait could bear the burdens of a man' life. The religious idea that, the possibility of confessing one's sins or saying a prayer could bring God's forgiveness. This idea is confirmed by Hallward, when he asks Dorian to join him in a prayer in order to wash away his sins.

"Let us kneel down and try if we cannot remember a prayer. Isn't there a verse somewhere, though your sins be as scarlet, yet I will make them as white as snow?"10

As far as the aspect of this supernatural event is concerned, I can notice that it is molded in the form of a detective novel. The supernatural here is associated with all the characteristics of the detective novel, which are murder, blackmail and spying. The event is murder of a painter, and an attempt on the murderer's part to destroy all the traces of his abomination, in order to make Alan Campbell destroy the body of the dead man, Dorian tries reasoning and persuading. But he fails and then resorts to blackmail Alan Campbell. I can notice the style Oscar Wilde makes Dorian use in order to express his determination.

He could see no change, save that in the eyes there was a sign of cunning and in the mouth the curved wrinkle of the hypocrite...",11

\footnotetext{
${ }^{9}$ Oscar, Wilde- The picture of Dorian Gray $\mathbf{P . 1 9 2}$

${ }^{10}$ Oscar, Wilde- The Picture of Dorian Gray $\mathbf{P . 1 7 5}$
} 
Dorian's only good action is condemned to be in vain. He expects his good action to cleanse the evidence of his corruption and crimes. And he is deeply disappointed because, what he considers to be good action is actually a brutal separation from a working-class village girl, who has put all her faith in him. Then, instead of bearing lines of cruelty as usual, or instead of bearing lines of a good moral change, the portrait shows signs of cunning and hypocrisy. Why did the portrait remain indifferent to Dorian's resolution to follow a path of virtue?

Since I have already established relationship and the interchange that exist between the portrait and Dorian Gray, the reader may be surprised to notice that, in spite of these different links, the portrait did not receive the change in Dorian's attitude. In fact, Dorian's attempt to make the portrait bear good lines is not sincere. The 'real Dorian'-that is the portrait- has for a long time been growing old, corrupted and loathsome, and any reverse process should follow the same slow course of changes. It is only out of curiosity, that Dorian has spared Hetty Merton. He wants to convince himself that he is not completely lost, and that he still remains susceptible to good changes and betterment. He wants to trap with his own soul and play with it. He knows that he is engaged in an irreversible process of evertasting new sensations and pleasures. He is conscious that the can never be get rid of the influence of Lord Henry's theories, that repression is evil and that,

'the only way to get rid of a temptation is to yield to it. Resist it, and your soul grows sick with longing for things it has forbidden to itself, desire for what its monstrous laws have made monstrous and unlawful, 12

The soul, as described in the portrait, is not deceived by this attempt to flatter the self, in believing that a real and definite change could take place. That is why, Dorian's soul, by means of the portrait, refuse to fulfill his expectations. So, the sympathy and the interdependence between Dorian and his portrait are still valid, and thanks to them, Dorian's soul could foresee the selfishness of its bearer. Moreover, if Dorian's portrait had to bear new lines of virtue, it would not be a sudden change as he expected it. It should be a slow and progressive process.

Oscar Wilde conveys this supernatural event with the use of certain elements such as superstition, mirror and a psychologically distressing atmosphere of terror. Superstition is part of the supernatural. It is based on irrational beliefs and association of ideas that give birth to things. After the death of a man who was supposed to be a beater, Dorian believes that something bad is going to happen to him or to one of his friends. He considers the death of this man as a bad omen. The use of mirror is recurrent in the novel. It is with an oval glass, that Dorian Gray first convinces himself of the change in the expression of the portrait. Then, so far as the portrait could reveal the reality of Dorian's soul, I can associate it with a mirror. The portrait is the mirror, the faithful reflection and expression of Dorian's own life and soul. As a result, he decides to destroy the mirror, which is one of the proofs of his depravity and decay. For, the mirror enables him to confront his physical beauty with the corruption and sins that are visible in the portrait.

"'Then he loathed his own beauty, and flinging the mirror on the floor, crushed it into silver splinters beneath his heed." 13

Oscar Wilde also surrounds this supernatural event with a psychological atmosphere of terror that is distressing for Dorian's Gray who does not know which way to turn. Dorian is troubled by the wind shaking the windows, by the falling of dead leaves, by the footsteps or faces of men. In short he is haunted by his past sins. Moreover, his failure to improve the dreadful lines of the portrait by doing good actions, contribute to his discouragement and he lost hope in everything in life. This supernatural event is a psychological kind, because it is troubling, confusing and disturbing for the mind. It has a final effect of convincing Dorian that he is damned, that he cannot change or even improve. Dorian Gray has also come to the conclusion that degrading moral state. After the of Dorian desire to reform himself, and of the capacity he display for self-denial in the hope that one day he will be able to wipe off every sign of sin from the portrait, he becomes conscious of the fact that nothing he can do would cleanse him, till he has confessed his sins. But he finds it impossible to confess.

${ }^{11}$ Oscar, Wilde- The Picture of Dorian Gray P.245

${ }^{12}$ Oscar, Wilde- The Picture of Dorian Gray P.25-26

${ }^{13}$ Oscar, Wilde- The Picture of Dorian Gray P.244 
Then, overpowered by dejection, Dorian Gray decides to destroy the main evidence of his foulness and corruption. He even wonders why he has kept it so long. And when he actually stabs the picture, he immediately dies. 'When they entered they found hanging upon the wall, a splendid portrait of their master as they had last seen him, in all the wonder of his exquisite youth and beauty. Lying on the floor was a dead man, in evening dress, with a knife in his heart. He was withered, wrinkled and loathsome of visage. It was not till they examined the rings that they recognized who it was." 14

With this other supernatural event, we reach the quintessence of the supernatural in its development in the novel. If Dorian died because he had stabbed the picture, his death is the result of the interchange that took place from the beginning when he became jealous of his own portrait. It was from that time, that the portrait, out of a strange sympathy, accepted to destroy the picture with a knife to avoid Dorian's pain, Dorian would have died. It seems that, Dorian had foreseen that danger, that he pleaded with Basil, not to destroy the picture.

'Don't, Basil, don't he cried. It would be murder!", 15

As a matter of fact, Basil would have committed a murder, if he had really stabbed the picture as a he intended to do. It would be murder on Basil's part, because the communication between Dorian and his soul was already realized. The interchange between the picture and Dorian had already taken place. If Dorian Gray died because he stabbed his own picture; if the servants, instead of seeing the knife in the canvas, saw it in their master's heart, it is the result of a narcissistic attitude adopted by Dorian. Dorian Gray fell in love with the portrait Hallward painted of him. He fell in love with his own beauty, and even became jealous of the portrait. So, the portrait being a faithful representation, a perfect image of Dorian Gray. The portrait was only a means used by Oscar wilde to show the evidence of Dorian's narcissistic attitude, and the reality of his sins, Conscience and soul. Dorian's death was then a suicide, because he could no longer bear the mental strain caused by the consciousness he had of the continual degradation of his soul. The interchange between the canvas, where the knife be seen, and Dorian's heart, is the result of a mysticism created by Oscar Wilde. It is mysticism because Dorian could not stand his own picture and pretended to stab it. Dorian, in stabbing the portrait, had stabbed his own soul.

So, after Dorian's death, the portrait once again changed places with Dorian. The portrait gained back its youth and beauty, whereas Dorian became withered and wrinkled as he normally should be. It seems that the contract between the portrait and Dorian Gray had suddenly come to an end. If Dorian died in stabbing his, it is because Oscar Wilde had to find a suitable end for his story. An end that fitted with the supernatural line he took up from the beginning, with the change in the portrait. If Dorian Gray lived on after the destruction of his portrait, the story would have no acceptable end, because of the harmony already established between the portrait and its owner. If the story continued after the destruction of the portrait, Dorian Gray would then be living without his soul, which is quite out of question.

Nevertheless, Dorian enjoys an eternal youth because his terrible wish has been granted. It is after the changes brought in the portrait by his cruelty towards Sibyl Vane, and the latter's suicide, that Dorian Gray first becomes aware that is going to benefit from an eternal youth. As years pass by, Dorian Gray is convinced of his advantage over people and the ease of his life. People begin to notice that time has no effect upon his body. Rumours are spread about his surprisingly permanent youth. This eternal youth enjoyed by Dorian Gray is the result of an affinity that was born between his portrait and himself. That eternal youth enables Dorian Gray is not assassinated by James vane who has sworn to avenge his sister's death. Eighteen years later Dorian is till the same, and James Vane concludes that it could not possibly be the man he is looking for, because prince charming, as Dorian is called, should be about forty years old.

"...For the face of the man he had sought to kill had all the bloom of boyhood, all the unstained purity of youth... it was obvious that this was not the man who had destroy her life.",16

\footnotetext{
${ }^{14}$ Oscar, Wilde- The Picture of Dorian Gray P.248

${ }^{15}$ Oscar, Wilde- The Picture of Dorian Gray $\mathbf{P . 3 5}$

${ }^{16}$ Oscar, Wilde- The picture of Dorian Gray P.211-12
} 
Thus, youth has proved to be something good for Dorian since it could rescure him from death. It is because Dorian appreciated the importance, the wonders of youth that the wished he could always remain young and that the portrait would grow old. The very fact that the painting changes, places this story in the realm of the supernatural.We are shocked and surprised by that sudden change in the portrait. But how can we explain such a change and to what extent is it possible?

\subsection{Explanation of the Supernatural in the Picture of Dorian Gray}

The first explanation that comes into our mind is that the picture, hidden away in the forsaken playroom of Dorian's innocent childhood, has suffered from dust and mildew. The effects of dust or humidity on clothes or papers that are stocked in places which are shut up from the open air are the changes of color and the fact that they are eaten away by microscopic organisms. If we take the case of books, the change in the portrait can be explained. A book that is exposed to dust and humidity becomes yellow, and is full of little holes made by tiny animals such as bookworms. The same thing can happen to clothes that are not preserved from dust and mildew.

The second explanation that is possible, according to us, is based on the paints used by Basil. If the paints that Basil has used were too old, the portrait in drying up would become had some mineral elements or some wretched mineral poison in is exposed to the sea. We can notice such a rottenness in cars that are always exposed to sea air. But all these attempts to give scientific explanations are destroyed by the smoothness of the surface of the canvas.

As a matter of fact, ifthe change in the portrait was actually due to dust, mildew or the paints used by Basil, the surface of the canvas would not remain smooth. Asperities would have appeared on the surface of the painted canvas, and they would have been palpable.

Nevertheless, an acceptable explanation remains possible. It is usually admitted that the face is the outward form of the soul. As such, the face expresses all the feelings of the soul. That phenomenon is the illustration of the harmony which exists between the body and the soul. A beautiful face should reveal an inward spirituality, whereas an ugly face should reveal an inward foulness.

As far as Dorian is concerned, the harmony, the relationship that should exist between the face and the soul, are suppressed and transferred to the painting Basil Hallward has made of him. The harmony and relationship that exist between the soul-an abstract thing-and the body-an external appearance-are the symbol of a unity. The kind of religious unity that exists in the trinity. In consequence of this phenomenon, they form a whole, and one element cannot be dissociated from the others. The soul or the conscience cannot be separated from the body: they constitute uniqueness. And that is why owing to Dorian's own wish the wickedness, the sins and the foulness recorded by his soul, choose to appear in his portrait, because they cannot appear in his face. So, like the soul in a man, the picture becomes something alive, and cannot help expressing Dorian's moral behaviour or his spiritual one.

But the fact that the soul can have an influence on the external appearance of our body, is certainly a question of belief, some people think that there are no such things as soul, and conscience. That only what we can touch and cross-examine, is the reality of life. According to people who hold such an opinion, the belief in the harmony and relationship between the soul and the body, or in the supernatural changes in the portrait are the result of ignorance: a weakness to give a scientific explanation to unusual things. Thus, thunder which is the sound that follows, and is caused by a lightning discharge, is considered in our African societies as the fight between two gods : the god of Africa and the gods of other lands. And the clap of thunder is supposed to be the outcome of the noise of their fight.

"... It is said that the roll of thunder and the

flash of lightning are their angry roar and the

fire from the fearful clashing of their swords"17

Indeed, Oscar Wilde made a considerable use of religious ideas and beliefs. The religious ideas for instance, that as a consequence of the realization of a portrait could bear the burdens of a man's life. The religious idea that, the possibility of confessing one's sins or saying a prayer could bring God's

\footnotetext{
${ }^{17}$ Wa Thiong'o, Ngugi-Petals of Blood (London, 48 Charles Street, Heineman Educational Books Ltd., 1977,) P. 68
} 
forgiveness. This idea is confirmed by Hallward, when he asks Dorian to join him in a prayer in order to wash away his soul.

Let us kneel down and try if we cannot

Remember a prayer. Isn't there a verse somewhere?

'though your sins be as scarlet, yet I will make

them as white as snow ?... ${ }^{18}$

As far as the aspect of this supernatural event is concerned, we can notice that it is moulded in the form of a detective novel. The supernatural here is associated with all the characteristics of the detective novel, which are murder, blackmail and spying. The event is the murder of a painter, and an attempt on the murderer', part to destroy all the traces of his abomination, in order to make people think that he was not at home when Basil was assassinated. To avoid the risk of discovery, Dorian goes out again and rings the bell to make his servant think that he has not met Hallward, and to get a good alibi.

\section{'I am sorry to have had to wake you up, \\ Francis' he said, stepping in ; 'but I had \\ forgotten my Latchkey. What time is it? 'Ten \\ minutes past two, sir, answered the man,... ${ }^{19}$}

Moreover, as soon as Dorian notices the changes in the portrait, he gets the idea that he is being spied on, and this thought mars most of his moments of pleasure. Besides, in order to make Alan Campbell destroy the body of the dead man, Dorian tries reasoning and persuasion. But he fails and then resorts to blackmail. We can notice the style Oscar Wilde makes Dorian use in order to express his determination.

$$
\begin{aligned}
& \text { If you don't help me I must sendit. If } \\
& \text { you don't help me, I will send it..."20 }
\end{aligned}
$$

Finally, we cannot help mentioning the striking fashion in which Oscar Wilde makes use of certain colours that fit in with this supernatural event. 'Black' and 'Dark' for example, are regularly used and have something to do with the symbolism of these colours. 'Black' and 'Dark' are the colours used for solemn ceremonies or to mourn people. 'Black' and 'Dark' are accomplices of strange deeds, and they favour many odd things. 'Red' too, is regularly used, and often symbolizes tragedy. It is a colour usually associated with blood. So, when Dorian kills hands of the portrait. It is a colour that also helps attract the attention of people. Together with 'Red ' go other colours such as, 'Scarlet'- 'Crimson' and 'Vermilion'.

\section{CONCLUSION}

In short, this supernatural event introduced by Oscar wilde, allows no doubt about the harmony and interrelation between Dorian and his picture, or between Dorian and his soul. The dreadful setting in which this supernatural event once occurs, and the colours associated with it, make us accept once and for all, the interchange between the portrait and Dorian Gray. Our heart now beats in unisson with Dorian's. We feel his ephemeral moments of joy: the joy of keeping an eternal physical beauty. The different changes in the portrait, that we have discussed till now, and this supernatural event in particular, help up to understand that, soul, conscience and body are one and the same thing. That is why, in trying to destroy one, Dorian Gray destroys the others. And Oscar Wilde succeeded in introducing supernatural event with an effect of surprise. This supernatural event is one of horror and blood, because it is connected with death: the death of a man who tasted almost all the pleasures and sins he could dream of.

The supernatural side in The Picture of Dorian Gray is the summing up of many supernatural event in one theme. Thus, the events give different aspects to that mystic story. First of all, the novel is, in fact, the story of a man and his soul. By means of some fantastic supernatural changes, it gives a vivid

\footnotetext{
${ }^{18}$ Wilde, Oscar-The Picture of Dorian Gray. P. 175

${ }^{19}$ Wilde, Oscar-The Picture of Dorian Gray. P. 178

${ }^{20}$ Wilde, Oscar-The Picture of Dorian Gray. P. 172
} 
carefully considered exposure of the corruption of a soul, with a plain moral driven home to the effect, that vice and crime make people coarse and ugly.It is also the story of an extraordinary harmony, by means of a mysterious affinity, a young man transfers age and corruption to a portrait of himself, retaining his appearance of innocence through a life- time of vice, until he and the portrait changes places again in the end. Then it is the story of a man who abuses life. By means of an abnormal influence due to a strange book and a philosophy, Lord Henry- Oscar Wilde's perfect dandy -expounds to Dorian Gray a paradoxical philosophy of dandyism which shocks Basil Hallward but appeals to the young narcissist. In the passion of his self-love Dorian distorts this doctrine and becomes a fallen dandy, corrupting all those who accompany him along his path and murdering his conscience, Basil Hallward. Finaly, in self-inflicted death, Dorian meets the punishment of excessive self-love.

Besides, the novel is written in the Victorian spirit that 'living was a desperate struggle between the force of good and the power of darkness'. Dorian's story is that of a man who is permanently trying to overcome the terrible struggle of one divided and torn between two opposed forces. So, when for the first time in his life, Dorian yields to the evil side of his nature, he decides to write a passionate letter to the girl he has hurt. Unfortunately for him, his attempt to obtain forgiveness by confessing his sin is to be in vain. It is too late because Sibyl Vane is already dead. Then Dorian-seing that the portrait enacts the process of his changing and records the gradual changes due to evil and the misfortunes of age-undertakes a second action in order to modify the horrible line his portrait. He cuts short his loveaffair with Hetty Merton. But this last attempt to better himself is unsuccessful. The expression of the portrait shows him that he is trying to be cunning. It is the inward struggle of a man, ceaselessly tasting ruthless behavior and guilty repentance. It is inward struggle of a man unremittingly living in a simultaneous desire to conceal his bad actions and to confess them. Still, this inward struggle does not put an end to the unity between soul and body, or Dorian and his portrait. For a life time, Dorian Gray enjoys the pleasure of a double life. Blinded by self-love, corruption and crime, Dorian thinks that soul or conscience could be parted with, and in this attempt to get rid of one, he kills himself. He learns like the fisherman, in the Fisherman and his soul, that even if one can momentarily ignore the voice of one's soul, the latter always intervenes before one's death, in order to get back his right to rule man's life and to decide that the soul, like the shadow of the body cannot effectively be cut off or wrenched from the body.

" $\ldots$ and when he had reached the dry shore he laughed again, and held out his arms to his soul. And his soul gave a great cry of joy and ran to meet him, and entered into him., ${ }^{, 21}$

So, the soul and the body are linked in a sort of divine unity. And thanks to this unity, Dorian experiences the double life symbolized by the man and his portrait, youth and age, beauty and ugliness, body and soul, freedom and conscience, life and art.

All these supernatural changes and the lessons they give are involved in a gloomy atmosphere specially created by Oscar Wilde, in order to convey the moral of his story to the reader. Not only does he use atmosphere, but he also uses meaningful colours, strange words, elements of detective novels, paradoxes to name a few. Moreover, improbable through the plot may be, it keeps one tenterhooks so that, one cannot put down the book at the end of a chapter, but must look over the next leaf to see what is going to happen. However, it is not an entire success. For, the narrative is too frequently interrupted by Wilde's aesthetic preaching by useless displays of aesthetic erudition, by unnecessary description of works of art, especially in chapter 11, which bores us and almost makes us forget the thread of the narrative. Nevertheless, it fits in the general purpose of Dorian's need to use the work of art as a means of forgetfulness, in making use experience the same feeling as Dorian: a Desire to forget the dreadful portrait. On the whole, Oscar Wilde's own statement gives the moral of this fantastic story:

“...All excess, as well as all renunciation, brings its own punishment. The painter, Basil Hallward, worshipping physical beauty for too much, as most painters do, dies by the hand of one in whose soul he has created a monstrous and absurd vanity. Dorian Gray having led a life of mere sensation and pleasure tries to kill conscience, and at that moment he kills himself,"

\footnotetext{
${ }^{21}$ Oscar, Wilde- The picture of Dorian Gray PP.8-9

${ }^{22}$ Oscar, Wilde- The picture of Dorian Gray PP.8-9
} 
Then we have to control, or moderate our excessive energy in everything, because if we give way to it freely, it will lead us to disaster. All in all, the result of reading Wilde's story is anything but depressing. Yet, his sunny disposition, his happy sense of humour, the sheer beauty of his craftsmanship redeems the cruelty or sadness of the theme.

In short, the different changes in the portrait, that we have discussed till now, and this supernatural event in particular, help up to understand that, soul, conscience and body are one and the same thing. That is why, in trying to destroy one, Dorian Gray destroys the others. And Oscar Wilde succeeded in introducing supernatural event with an effect of surprise. This supernatural event is one of horror and blood, because it is connected with death: the death of a man who tasted almost all the pleasures and sins he could dream of.

Nevertheless, Dorian enjoys an eternal youth because his terrible wish has been granted. It is after the changes brought in the portrait by his cruelty towards Sibyl Vane, and the latter's suicide, that Dorian Gray first becomes aware that is going to benefit from an eternal youth. As years pass by, Dorian Gray is convinced of his advantage over people and the ease of his life. People begin to notice that time has no effect upon his body. Rumours are spread about his surprisingly permanent youth. This eternal youth enjoyed by Dorian Gray is the result of an affinity that was born between his portrait and himself. That eternal youth enables Dorian Gray is not assassinated by James vane who has sworn to avenge his sister's death. Eighteen years later Dorian is till the same, and James Vane concludes that it could not possibly be the man he is looking for, because prince charming, as Dorian is called, should be about forty years old.

"...For the face of the man he had sought to kill had all the bloom of boyhood, all the unstained purity of youth... it was obvious that this was not the man who had destroy her life.",23

Thus, youth has proved to be something good for Dorian since it could rescure him from death. It is because Dorian appreciated the importance, the wonders of youth that the wished he could always remain young and that the portrait would grow old. The very fact that the painting changes, places this story in the realm of the supernatural. In the Element Encyclopedia of Ghosts and Hauntings by Theresa Chung, supernatural is defined as: Any experience, occurrence, manifestation or object that is beyond the laws of nature and science and whose understanding may be said to lie with religion, magic or the mystical After Dorian's pronouncement that he would give his soul for the painting to grow old instead of him, the first time the painting changes is after he rejects Sibyl. The supernatural side in The Picture of Dorian Gray is the summing up of many supernatural event in one theme. Thus, the events give different aspects to that mystic story. First of all, the novel is, in fact, the story of a man and his soul. By means of some fantastic supernatural changes, it gives a vivid carefully considered exposure of the corruption of a soul, with a plain moral driven home to the effect, that vice and crime make people coarse and ugly.

It is also the story of an extraordinary harmony, by means of a mysterious affinity, a young man transfers age and corruption to a portrait of himself, retaining his appearance of innocence through a life- time of vice, until he and the portrait changes places again in the end.

Then it is the story of a man who abuses life. By means of an abnormal influence due to a strange book and a philosophy, Lord Henry- Oscar Wilde's perfect dandy -expounds to Dorian Gray a paradoxical philosophy of dandyism which shocks Basil Hallward but appeals to the young narcissist. In the passion of his self-love Dorian distorts this doctrine and becomes a fallen dandy, corrupting all those who accompany him along his path and murdering his conscience, Basil Hallward. Finaly, in self-inflicted death, Dorian meets the punishment of excessive self-love.

Besides, the novel is written in the Victorian spirit that 'living was a desperate struggle between the force of good and the power of darkness'. Dorian's story is that of a man who is permanently trying to overcome the terrible struggle of one divided and torn between two opposed forces. So, when for the

${ }^{23}$ Oscar, Wilde- The picture of Dorian Gray P.211-12 
first time in his life, Dorian yields to the evil side of his nature, he decides to write a passionate letter to the girl he has hurt. Unfortunately for him, his attempt to obtain forgiveness by confessing his sin is to be in vain. It is too late because Sibyl Vane is already dead. Then Dorian-seing that the portrait enacts the process of his changing and records the gradual changes due to evil and the misfortunes of age-undertakes a second action in order to modify the horrible line his portrait. He cuts short his loveaffair with Hetty Merton. But this last attempt to better himself is unsuccessful. The expression of the portrait shows him that he is trying to be cunning. It is the inward struggle of a man, ceaselessly tasting ruthless behavior and guilty repentance. It is inward struggle of a man unremittingly living in a simultaneous desire to conceal his bad actions and to confess them. Still, this inward struggle does not put an end to the unity between soul and body, or Dorian and his portrait. For a life time, Dorian Gray enjoys the pleasure of a double life. Blinded by self-love, corruption and crime, Dorian thinks that soul or conscience could be parted with, and in this attempt to get rid of one, he kills himself. He learns like the fisherman, in the Fisherman and his soul, that even if one can momentarily ignore the voice of one's soul, the latter always intervenes before one's death, in order to get back his right to rule man's life and to decide that the soul, like the shadow of the body cannot effectively be cut off or wrenched from the body.

" $[\ldots . .$.$] and when he had reached the dry shore he laughed again, and held out his arms to$ his soul. And his soul gave a great cry of joy and ran to meet him, and entered into him." ${ }^{, 2}$ So, the soul and the body are linked in a sort of divine unity. And thanks to this unity, Dorian experiences the double life symbolized by the man and his portrait, youth and age, beauty and ugliness, body and soul, freedom and conscience, life and art.

All these supernatural changes and the lessons they give are involved in a gloomy atmosphere specially created by Oscar Wilde, in order to convey the moral of his story to the reader. Not only does he use atmosphere, but he also uses meaningful colours, strange words, elements of detective novels, paradoxes to name a few. Moreover, improbable through the plot may be, it keeps one tenterhooks so that, one cannot put down the book at the end of a chapter, but must look over the next leaf to see what is going to happen. However, it is not an entire success. For, the narrative is too frequently interrupted by Wilde's aesthetic preaching by useless displays of aesthetic erudition, by unnecessary description of works of art, especially in chapter 11, which bores us and almost makes us forget the thread of the narrative. Nevertheless, it fits in the general purpose of Dorian's need to use the work of art as a means of forgetfulness, in making use experience the same feeling as Dorian: a Desire to forget the dreadful portrait. On the whole, Oscar Wilde's own statement gives the moral of this fantastic story:

"[.....] All excess, as well as all renunciation, brings its own punishment. The painter, Basil Hallward, worshipping physical beauty for too much, as most painters do, dies by the hand of one in whose soul he has created a monstrous and absurd vanity. Dorian Gray having led a life of mere sensation and pleasure tries to kill conscience, and at that moment he kills himself,"25

Then we have to control, or moderate our excessive energy in everything, because if we give way to it freely, it will lead us to disaster. All in all, the result of reading Wilde's story is anything but depressing. Yet, his sunny disposition, his happy sense of humour, the sheer beauty of his craftsmanship redeems the cruelty or sadness of the theme.

\section{REFERENCES}

[1] Amadi, Elechi: The Great Ponds, London, Heinemann Educational books, 1970.

[2] Beckford, William: Vathek, London and Glasgow: Collins, 1887.

[3] Foreman,J.B. : Complete works of Oscar Wilde,London and Glasgow:Collins, 1977.

[4] Jean Nounadondé: Beauty as source of perfection in Oscar Wilde's The Picture of Dorian Gray. Post graduate dissertation,University of Abomey-Calavi,2013.

\footnotetext{
${ }^{24}$ Oscar, Wilde- The picture of Dorian Gray PP.8-9

${ }^{25}$ Oscar, Wilde- The picture of Dorian Gray PP.8-9
} 
[5] Wa Thiong'o, Ngugi: Petals of Blood, London, 48 Charles Street, Heineman Educational Books Ltd., 1977.

[6] Wilde, Oscar: The Picture of Dorian Gray, Michael Patrick Gillespie, Editor. Norton critical Edition. New York: W.W. Norton \&Company, inc., 2007.

[7] Wright,Austin: Victorian Literature: Modern Essays in criticism, New York: Oxford University Press, 1961.

\section{AUTHOR's BIOGRAPHY}

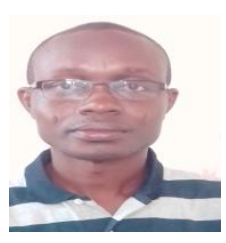

Jean Sohoutou Nounadondé, is Doctor to be of University of Abomey-Calavi.He is English teacher in Benin Secondary schools. He also assists his professor to teach British Civilisation and literature at University of Abomey-Calavi

Citation: Jean S., Nounadonde. "The Supernatural Side in Oscar Wilde'S The Picture of Dorian Gray." International Journal on Studies in English Language and Literature (IJSELL), vol 5, no. 9, 2017, pp. 38-50. doi:http://dx.doi.org/10.20431/2347-3134.0509005.

Copyright: (C) 2017 Authors. This is an open-access article distributed under the terms of the Creative Commons Attribution License, which permits unrestricted use, distribution, and reproduction in any medium, provided the original author and source are credited. 